\title{
Extending the boundaries of the Declaration of Helsinki: a case study of an unethical experiment in a non-medical setting
}

Elihu D Richter, Paul Barach, Tamar Berman, G Ben-David, Zvi Weinberger Hebrew University-Hadassah, ferusalem, Israel, University of Chicago, and Ferusalem College of Technology

\begin{abstract}
To examine the ethical issues involved in governmental decisions with potential health risks, we review the history of the decision to raise the interurban speed limit in Israel in light of its impact on road death and injury. In 1993, the Israeli Ministry of Transportation initiated an "experiment" to raise the interurban speed limit from 90 to $100 \mathrm{kph}$. The "experiment" did not include a protocol and did not specify cut-off points for early termination in the case of adverse results. After the raise in the speed limit, the death toll on interurban roads rose as a result of a sudden increase in speeds and case fatality rates. The committee's decision is a case study in unfettered human experimentation and public health risks when the setting is non-medical and lacks a defined ethical framework. The case study states the case for extending Helsinki type safeguards to experimentation in non-medical settings.

(Fournal of Medical Ethics 2001;27:126-129)
\end{abstract}

Keywords: Declaration of Helsinki; human experimentation; speed limit

\section{Introduction}

Medical ethics deals with, among other things, safeguarding the decision making process to do with matters of life and death. Social ethics deals with resolving the conflicts from use and abuse of resources, goods, services and products that sometimes produce pleasure for many, but pain and suffering for some. We present a case study of an episode at the interface between medical and social ethics: the "experiment" by the Israel Ministry of Transportation to raise speed limits on selected high-speed roads, in November 1993. The case study calls attention to the need for extending Declaration of Helsinki type safeguards, now standard in medical experiments, to decisions made outside conventional medical settings, but which may have an impact on public health.

\section{The case study}

THE RECOMMENDATION

In 1993, a commission appointed by the Minister of Transportation of the government of Israel recommended raising the speed limit on selected high-speed interurban roads from 90 to $110 \mathrm{kph}$ (56 to $64 \mathrm{mph}$ ), for all vehicles, including trucks. ${ }^{2}$ The commission also recommended lowering the speed limit in highly crowded urban areas to 30 $\mathrm{kph}$. The stated justifications for raising the speed limit were (1) to bring road speed limits in Israel into line with European Union (EU) speed limits; (2) to set the legal thresholds above observed rises in actual travel speeds on high-speed roads; (3) and to gain the economic benefits of time-saving from interurban travel at higher speeds. The commission summarised much of the epidemiological literature on the risks for increases in deaths from raised speed limits. It noted data from Sweden showing that speeds just below $90 \mathrm{kph}$ provide an optimum cost-benefit relationship for society at large, and that the European Union (EU) retained lower speed limits for trucks $(70 \mathrm{kph}$ for double trailers, $80 \mathrm{kph}$ for single trailers, and $90 \mathrm{kph}$ for lighter weights, respectively). It predicted that even though there would be zero to two more deaths per year on the high-speed road, death tolls overall would drop by some eight to ten, as traffic would be diverted from higher risk low-speed roads to lower risk high-speed roads. It concluded that environmental measures to remove hazards at designated black spots would cancel the well recognised effect of increased speeds increasing injury severity.

The report published by the commission included dissenting statements. These warned against ignoring the large number of studies showing that raised speed limits were followed by raised death tolls; that raised speed limits themselves induced even higher travel speeds; and that the spillover effect of speed addiction would create special risks from crashes with trucks and vehicles driven by young drivers..$^{3-13}$ The dissenters predicted there would be a rise of 40-60 extra deaths, mainly from the spillover effect of a $110 \mathrm{kph}$ speed limit. ${ }^{1-13}$ The commission's report ignored objections from the Israel Defense Forces' (IDF) road accident safety research division. The IDF warned that a $100 \mathrm{kph}$ speed limit would increase death and injuries from crashes involving military drivers and soldiers, both on- and off-duty.

The most important point that the dissenters raised was that the government's decision to carry 
out the "experiment"- the term used by the then director of the Road Safety Authority-did not include a protocol with objectives, a study design, methods, a timetable, and measurable outcome variables serving as end points for evaluation, and did not specify cut off points for early termination in the case of adverse results, as is required for medical trials of new therapeutic procedures. ${ }^{14}$ The dissenters characterised the decision as an unethical exercise in human experimentation.

\section{What happened}

November 1993, the first month of enactment of $100 \mathrm{kph}$, was the worst ever for road death tolls over the past decade. Sixty-one (61) persons were killed, with a marked rise in case fatality, an index of severity of crash.

\section{THE SUPREME COURT APPEAL}

In January 1994, the Supreme Court rejected a petition from two community groups to cancel the Minister of Transportation's decision..$^{15}$ The petition called attention to the fact that the government had a legally binding obligation to preserve and protect the life of its citizens. It contained a literature review of the effects of raised speed limits on speeds, spillover, and road deaths, and included a letter from Dr Allan Williams of the US Insurance Institute for Highway Safety. In the letter Dr Williams wrote: "It has been demonstrated conclusively that raising speed limits on major roads increases speeds and fatalities; lowering speed limits reduces speeds and fatalities ... these findings hold worldwide. There is no reason that any country, including Israel, will have findings that differ from this common experience... ."The Supreme Court judges ruled that it was not within their purview to determine the scientific validity of the prediction of one group of experts over another. The government attorney's brief included a promise to monitor the impact of the raised speed limit on travel speeds, but predicted that the death toll would drop with the rise in the speed limit. The brief stated that the government intended to raise the speed limit again to $110 \mathrm{kph}$, which in fact happened in 1995.

\section{Monitoring the trend in road deaths}

After the rise in the speed limit, monthly death tolls continued to remain high compared to the same months in the previous four years. ${ }^{16}{ }^{17}$ Subsequent trends indicated that increases in deaths on interurban roads and case fatality persisted for a five-year period, from 1993 through to 1998 . (Richter E D, unpublished data) The findings indicated there was a spillover effect on all other major highways and feeder roads. The rise in the death toll was in all crash types (except cyclists and pedestrians), especially those involving trucks, motorcyclists, a single vehicle and soldiers.

\section{Public challenge, government response: from 100 to 110 to $120 \mathrm{kph}$}

In July 1994, we sponsored an academic workshop on the findings from the first eight months of the so-called experiment. At the meeting, two senior medical officers from the Ministry of Health compared the situation to the French scandal when officials remained silent about blood for haemophiliacs contaminated by HIV. In October 1994, the government convened a special meeting to assess the impact of the raised speed limit. In 1995 the commission was reconvened to determine if there was a direct cause-effect relationship between the $100 \mathrm{kph}$ speed limit and the rise in the death toll. The commission's report and research papers acknowledged a rise in the death toll, but concluded that the increase in the speed limit was not the explanation. ${ }^{18-20}$ All these reports were critiqued for major methodologic flaws. ${ }^{21}$ Nevertheless, the commission ruled against raising the posted limit to $110 \mathrm{kph}$, as it had originally recommended. It further recommended reducing the speed limit of trucks back down to $90 \mathrm{kph}$.

Later in 1995, the government raised the legal threshold for enforcement of the speed limit to 110 $\mathrm{kph}$ without changing the posted level of $100 \mathrm{kph}$. In late 1999, senior police officials proposed raising the speed limit to $120 \mathrm{kph}$ for a new high-speed toll road. But the notion that the proposal was ethically problematic had by now penetrated the decision making process. ${ }^{22}$ In 2000 , the director of Israel's Road Safety Authority himself described the new proposal to raise the speed limit again, to $120 \mathrm{kph}$, as an unethical exercise in human experimentation, using language identical to that which the dissenters used in 1993 to oppose $100 \mathrm{kph}$ (statement by Shmuel Hershkowitz to Knesset economic committee, January 112000 ).

\section{$100 \mathrm{kph}$ : an unethical non-medical experiment}

The Ministry of Health saw the non-medical status of the decision making body as exempting the government commission's review of data, analysis, and interpretation from the ethical criteria of medical institutional review boards, which in Israel are called Helsinki committees (after the Declaration of Helsinki). Even though the outcomes, which were of such concern, from the experiment were death, injury, and disability, the commission was not subject to the reviews and safeguards now mandatory for clinical trials and epidemiological research in the medical world.

We suggest that the commission's lapses in evaluation and judgment directly resulted from its institutional framework and structure. No experts on trauma, epidemiology, ethics, or theology were included as voting members. There was no medical input into the commission's decision making process despite the increased population-wide risks for death and injury from road trauma. The Ministry of Health remained silent on the issue, even though individual epidemiologists were opposed.

We surmise that what happened here has happened in many other settings as well. A government can make a decision that increases the risks for death and injury without specifying criteria for presence of 
128 Extending the boundaries of the Declaration of Helsinki: a case study of an unethical experiment in a non-medical setting

Table 1 A comparison of two experiments: Tuskegee and the $100 \mathrm{KPH}$ experiment in Israel

\begin{tabular}{|c|c|c|}
\hline & Tuskegee experiment & The $100 \mathrm{kph}$ experiment \\
\hline Pathogen & Treponema pallidum - spirochete & Kinetic energy \\
\hline Source-mode of transmission & $\begin{array}{l}\text { Person-to-person, sexual contact or placental } \\
\text { transmission }\end{array}$ & $\begin{array}{l}\text { Vehicle-person impact, first, second and third } \\
\text { collision }\end{array}$ \\
\hline Exposure voluntary-involuntary & Voluntary - sexual intercourse & Involuntary: most victims passively exposed \\
\hline Addictive effects from exposure & No & Yes \\
\hline $\begin{array}{l}\text { Forewarning/prior consent to exposure to } \\
\text { pathogen }\end{array}$ & Probably not & Sometimes yes, mostly no \\
\hline Ethical issue & $\begin{array}{l}\text { Withholding effective treatment and total } \\
\text { cure from sick victims }\end{array}$ & $\begin{array}{l}\text { Reduction of severity of exposure to } \\
\text { population already at excess risk for death } \\
\text { and injury from road crashes }\end{array}$ \\
\hline Public health impact & $\begin{array}{l}\text { Slow progression of disease in all victims; } \\
\text { PYL }<10 \text { y (non-stochastic) }\end{array}$ & $\begin{array}{l}\text { Stochastic for event: all or nothing: increase in } \\
\text { risk in entire population }\end{array}$ \\
\hline $\begin{array}{l}\text { Degree of compulsion/power } \\
\text { relationships }\end{array}$ & $\begin{array}{l}\text { One powerless, voiceless subgroup: Black, } \\
\text { poor, southern in } 1950 \text { s, passive acquiesence } \\
\text { of uninformed black community }\end{array}$ & $\begin{array}{l}\text { Many powerless subgroups at excess risk: } \\
\text { occupants of motor vehicles struck by trucks; } \\
\text { pedestrians (aged, children, infirm); children } \\
\text { in fast vehicles; soldiers; truck drivers working } \\
\text { under incentive premiums }\end{array}$ \\
\hline $\begin{array}{l}\text { Role of "establishment", "power elites" } \\
\text { (mandarins, consultants, academics, } \\
\text { senior scientists) }\end{array}$ & $\begin{array}{l}\text { Initiated "experiment"; no known falsification } \\
\text { of data within study; withholding information } \\
\text { from powerless subgroup }\end{array}$ & $\begin{array}{l}\text { Encouraged and endorsed "experiment"; } \\
\text { misinformation to entire society; repression of } \\
\text { information on adverse effects, including } \\
\text { high-risk subgroups }\end{array}$ \\
\hline Scope & $\begin{array}{l}\text { Restricted to one group; experiment } \\
\text { terminated }\end{array}$ & Entire population; experiment expanded \\
\hline Motivations & $\begin{array}{l}\text { "Science", "knowledge", fame, prestige, } \\
\text { bureaucratic inertia }\end{array}$ & $\begin{array}{l}\text { "Cost-benefit", "rational policy", "EEC"; } \\
\text { consultant contracts, new highways }\end{array}$ \\
\hline $\begin{array}{l}\text { Adequacy of current standards for best } \\
\text { practice }\end{array}$ & Penicillin: good to excellent & $\begin{array}{l}\text { "Best" standards: outcome criteria not } \\
\text { explicitly defined }\end{array}$ \\
\hline Attitude of public & $\begin{array}{l}\text { Approval in early years; instant repudiation } \\
\text { following exposure in } 1970 \text { s }\end{array}$ & $\begin{array}{l}\text { Polls: majority supports } 100 \mathrm{kph} \text {; majority } \\
\text { opposes when told it causes increased death } \\
\text { and injury }\end{array}$ \\
\hline Institutional safeguards & None at time (1945-1970) & None at time (1993-1999) \\
\hline
\end{tabular}

increased risk - or its absence - and without including representatives of the medical and ethical community in the decision making process

100 kph: an Israeli Tuskegee experiment? "Do no harm" and "informed consent" are bedrock principles for evaluating proposals to carry out medical experiments in humans. ${ }^{123}$ The entire decision making process of the commission raised troubling questions concerning its attention to these principles. Was the decision to continue with the "experiment" after the first high monthly death tolls similar to what happened in the infamous Tuskegee experiment, in which physicians deliberately withheld penicillin from poor black sharecroppers with tertiary syphilis $?^{24}$ The experiment to raise the speed limit differed from the Tuskegee experiment in two important respects (table 1). First, the raised speed limit did not require drivers to increase their speed. Second, the subjects were not a deprived minority, dependent on the doctors and nurses in a controlled medical setting, but an entire population of drivers. The fact that the potential subjects were the entire population of drivers and passengers begs the questions of ethical oversight of decisions with population-wide impacts.

\section{Speed addiction and voluntary and involuntary risks}

We contrast the commission's policies and actions, and the inaction of medical authorities to protect the general public, with the consensus that there is a public health role for protecting non-smokers from the risks of environmental tobacco smoke. Are risks for injury and death increased not only for those who speed, but also for those road users - passengers and pedestrians-who are involuntarily exposed?

\section{Professional accountability}

We noted that the recommendations and risk assessments of the commission were contradicted by its own literature review. What is the case for the accountability of the professional members of the commission? Did the commission fail to satisfy criteria for meeting accepted standards for professional caution, judgment, prudence and accountability when making a decision concerning risk to the public? Did they consider evidence that the recommendations and risk scenarios represented the best possible interpretation of the available data? Is there an analogy here with the engineer who ignores his own or others' calculations of load tolerances and therefore is responsible by an error of omission if a bridge collapses or a ship sinks? Is there an analogy with a factory manager who knowingly exposes his or her workers to hazardous toxics? ${ }^{25}$

\section{The Benthamite dilemma: pleasure for most, pain for some}

The decision to increase the speed limit to $100 \mathrm{kph}$ is an example of the clash between the absolutist ethical principle that life and its preservation is an 
ultimate value and a Benthamite norm of the greatest good for the greatest number of people. ${ }^{26}$ Decisions in land transport tend to be presented in terms of a paradigm that weighs the economic benefits of fast transport of persons and goods, against the costs of injury and death to the unlucky minority. In the USA, this "minority" consisted of some 41,345 dead and 3,200,000 injured in 1999, and speeding was estimated to account for 12,477 $(30 \%)$ of the road death toll in $1998 .{ }^{27}{ }^{28}$ Death and injury are considered an unwelcome but necessary price to be paid by an unlucky minority for increasing happiness, pleasure and profit among the majority. In a medical setting, such a paradigm would be anathema.

\section{Conclusion}

Our proposal to extend the boundaries of the Declaration of Helsinki from medical to social experiments goes against recent pressures to restrict the scope of informed consent within medical experimentation. ${ }^{29}$ The commission's decision is a case study of the possibilities of unfettered human experimentation and fatal medical risks where ethical guidelines and oversight are lacking. In the non-medical setting, the increased risks are not directly personal, but statistical and involuntary, and the general public is unaware of its participation in the experiment.

In conclusion, the story of the decision in Israel to increase the speed limit to $100 \mathrm{kph}$ states the case for extending Helsinki-type safeguards to experimentation in non-medical settings with increased risk for death and injury.

Elihu D Richter, MD, MPH, is Head of the Center for Injury Prevention and Unit of Occupational and Environmental Medicine, Hebrew University-Hadassah School of Public Health and Community Medicine, Ferusalem, Israel. Paul Barach MD, MPH, specialises in Anaesthesia and Critical Care and is Director of the Center for Patient Safety, Pritzker School of Medicine, University of Chicago, Illinois, USA. Tamar Berman, $B A$, is a candidate for an MS degree in Environmental Sciences, Hebrew University. G Ben-David, PhD, is a Nuclear Physicist and an authority on speed cameras in the center. Zvi Weinberger, BS, is a Physicist and Chairman of the Department of Electrooptics, Ferusalem College of Technology and President Emeritus of Ferusalem College of Technology.

\section{References and notes}

1 Declaration of Helsinki. Helsinki, Finland. Adopted by the 18th World Medical Assembly, Helsinki, 1964 as amended by the 52nd World Medical Assembly, Edinburgh, Scotland, October 2000.

2 Livneh M. Report of expert committee appointed by minister of transportation, Israel Kessar to examine maximum permitted speed limits in israel. 1993 May 31 (in Hebrew).

3 Baum HM, Wells JK, Lund AK. The fatality consequences of the $65 \mathrm{mph}$ speed limit. Fournal of Safety Research 1991;22:171-7.

4 Chang G, Chen C, Carter E. Intervention analysis for the impacts of the $65 \mathrm{mph}$ speed limit on rural interstate highway fatalities. Fournal of Safety Research 1993;24:33-53.
5 Insurance Institute for Highway Safety. Speed limits and motor vehicle deaths: the two are connected. Status Reports 1989;25:2.

6 Garber S, Graham JD. The effect of the new $65 \mathrm{mph}$ speed limit on rural highway fatalities: a state-by-state analysis. Accident Analysis and Prevention 1990;22:137-49.

7 Gallagher S. Effects of the $65 \mathrm{mph}$ speed limit on rural interstate fatalities in New Mexico. Fournal of the American Medical Association 1989;262:2243-5.

8 Wagenaar AC. Effects of macro-economic conditions on the incidence of motor vehicle crashes. Accident Analysis and Prevention 1984;16:191-205.

9 National Research Council. 55 MPH: a decade of experience. Washington DC: US Department of Transportation, 1984

10 Nilsson G. Swedish National Road and Transport Research Institute (Vti) report 351. Reduction in the speed limit from 110 $k p h$ to $90 \mathrm{kph}$ during Summer 1989. Sweden: Swedish National Road and Transport Research Institute (Vti), 1990.

11 Casey SM, Lund AK. Changes in speed and speed adaptation following increase in national maximum speed limit. fournal of Safety Research 1992;23:135-46.

12 Mathews ML. A field study of the effects of drivers' adaptation to automobile velocity. Human Factors 1978;20:709-16.

13 Schmidt DF, Tiffin J. Distortion of drivers' estimate of automobile speed as a function of speed adaptation. Fournal of Applied Psychology 1969;53:536-9.

14 Schneller O. The $100 \mathrm{kph}$ experiment: your letter to the Minister [letter]. 1993, Dec

15 Neggar A. Metad: Society for War against Road Accidents v Minister of Transportation. Petition to Supreme Court, hearing 1994 Jan 13. This included letter from Allan F Williams, Sr Vice President for Research, Insurance Institute For Highway Safety. 1994 Jan 11.

16 Richter ED, Barach P, Krikler S, Damian D, Israeli A, Ben-David G, et al. Do higher speed limits kill? The $100 \mathrm{kph}$ "experiment": an epidemiologic evaluation [abstract]. Proceed"experiment": an epidemiologic evaluation [ab

17 Fishman RHB. Anti-speeding Israeli doctors. Lancet 1995;345: 1040.

18 Livneh M. Report of expert committee appointed to monitor and evaluate the influence of changes in permitted speed limits in Israel. Submitted to Minister of Transportation. 1995 Apr 1 (in Hebrew)

19 Hocherman I, Cohen A, Dubeh E. Trends in speed and road accidents on fast roads in Israel. Traffic and Transportation 1996; Nov:33-8 (in Hebrew).

20 Caspit N, Mehalel D, Livneh M. Influence of changed speed limits on road safety. Technion-Israel Institute of Technology Research Report no 97-248, 1997 May (in Hebrew).

21 Richter ED, Barach P, Ben-Michael E, Weinberger Z. Junk ethics and junk science in transport risk assessment. Proceedings of the 7th International Conference of the Israel Social Ecology and Environment Health Sciences 1999 Jun 13-18.

22 Richter ED, Ben-Michael E, Reingold SM, Fletcher E, Weinberger Z, Ginsberg G. Impacts of new highways on road deaths: a case study in risk assessment. International Archives of deaths: a case study in risk assessment. International Archives of Occupar.

23 National Commission for the Protection of Human Subjects of Biomedical and Behavioral and Biomedical Research. Belmont report: ethical principles and guidelines for the protection of human subjects of research. Washington DC: Government Printing Office, 1983

24 Jones J. Bad blood: the Tuskegee syphilis experiment. London: The Free Press, 1981.

25 Bingham E, Reddick E, Meader W, Rankin L, eds. Special issue: public health aspects of criminal prosecution of workplace related deaths, injury and disease. International fournal of Occupational Medicine and Toxicology 1994;3,4:200.

26 Bentham J. An introduction to the principles of morals and legislation. Oxford: Claroduction to the princi

27 US Department of Transportation. National Highway Traffic Safety Administration. Early assessment of 1999: crashes, injuries,
and fatalities. http://www.nhtsa.dot.gov/people/ncsa/reports/ and fatalities. http://vw

28 US Department of Transportation. National Highway Traffic Safety Administration. Traffic Safety facts 1998 (http:// www.nhtsa.dot.gov/people/ncsa/pdf.speeding98.pdf)

29 Brennan T. Proposed revisions to the Declaration of Helsinkiwill they weaken the ethical principles underlying human research? The New England fournal of Medicine 1999;341:527-31. 